\title{
Adverse Working Conditions and Mental Illness in Poultry Slaughterhouses in Southern Brazil
}

\author{
Condições Adversas de Trabalho e Doença Mental em Abatedouros de Aves \\ no Sul do Brasil
}

\author{
Claudio Simon Hutz ${ }^{*},{ }^{a}$ Cristian Zanon ${ }^{a} \&$ Hermindo Brum Neto $^{b}$ \\ ${ }^{a}$ Universidade Federal do Rio Grande do Sul, Porto Alegre, Brasil \& ${ }^{b}$ Ministério do Trabalho, Porto Alegre, Brasil
}

\begin{abstract}
Mental illness is one of the reasons for the great number of absences from work due to incapacity in Brazil. Recently, mental disorders were included in the list of occupational diseases of the International Labour Office. In spite of the difficulty in attributing a causal link between an inappropriate work environment and mental illness, studies have shown that workers exposed to high levels of stress are more likely to present psychopathological symptoms. The present study investigated the relationship between working conditions and the Neuroticism personality factor. Participants were 951 workers from southern Brazilian poultry slaughterhouses, who work in positions with varied levels of risk and stress. The neuroticism scores of such employees were compared with those of other samples. A scale which measures the Neuroticism factor in the model of the Big Five Personality Factor validated for use in Brazil was employed. The results showed that workers of the sectors in which the working conditions are highly stressful presented higher levels in all sub-factors of neuroticism than workers in other sectors and groups. These sectors also showed higher indexes of mental disorders. Keywords: Depression, anxiety, working conditions, mental health, neuroticism.
\end{abstract}

\begin{abstract}
Resumo
A doença mental é uma das causas atribuídas ao grande número de ausências no trabalho devido à incapacidade no Brasil. Recentemente, os transtornos mentais foram incluídos na lista de doenças profissionais do International Labour Office (Departamento Internacional do Trabalho). Apesar da dificuldade em atribuir um nexo de causalidade entre o ambiente de trabalho inadequado e a doença mental, estudos têm mostrado que trabalhadores expostos à altos níveis de estresse são mais suscetíveis a apresentar sintomas psicopatológicos. O presente estudo investigou a relação entre os níveis do fator de personalidade neuroticismo e as condições de trabalho. Os participantes foram 951 trabalhadores de abatedouros de aves do sul do Brasil, que trabalham em funções com níveis variados de risco e estresse. As pontuações de neuroticismo destes funcionários foram comparados com os de outras amostras. Utilizou-se uma escala que mede o fator neuroticismo no modelo do Fator de Personalidade Big Five, validado para uso no Brasil. Os resultados mostraram que os trabalhadores dos setores em que as condições de trabalho são altamente estressantes apresentaram níveis mais elevados em todos os subfactors de neuroticismo do que trabalhadores de outros setores e grupos. Estes setores apresentaram maiores índices de transtornos mentais.

Palavras-chave: Depressão, ansiedade, trabalho condições, saúde mental, neuroticismo.
\end{abstract}

Exporting chicken meat constitutes an expanding productive activity in Brazil which is currently the second largest exporter of poultry in the world. It is estimated that there has been an exponential increase in the slaughtering of chickens in recent years by Brazilian slaughterhouses to supply both the domestic and foreign markets (União Brasileira de Avicultura [Ubabef], 2011).

Besides the notable economic success achieved, the data of some Brazilian slaughterhouses are impressive concerning the mental health of their production line workers. This study aims to present the results of an action executed by the Ministry of Labor, with the assistance of the Federal University of Rio Grande do Sul, with the objective to evaluate possible relationships between adverse working conditions and becoming mentally ill in slaughterhouses in the southern region of Brazil. 


\section{Becoming Mentally ill at Work}

Recently (March 2010) mental and behavioral disorders were included in the list of occupational diseases of the International Labour Office (ILO, 2010). According to the official Brazilian statistics (Ministry of Social Security, 2010), mental illness is one of the main reasons for a great number of absences from work due to temporary or permanent incapacity in Brazil. In spite of the methodological difficulty to attribute a causal link between working in an environment with adverse conditions and becoming mentally ill (Borsoi, 2007), the association between these variables has been documented by the relevant literature (Karasek, 1979; Mausner-Dorsch \& Eaton, 2000).

It is possible that adverse or inadequate working conditions are a source of stress and lead to developing anxiety and depression (Plaisier et al., 2007). For this author, social support is an important factor in reducing these adversities. According to Chen, Siu, Lu, Cooper and Phillips (2009), even small stressful situations in daily activities can activate a factor of cognitive vulnerability that can lead to depression. Some possible stressors mentioned in the literature are: lack of personal sense concerning the activities developed, underuse of skills, and work overload.

One model used in research investigating stressors related to the work environment is the Demand-Control-Model (Karasek, 1979). This model assumes that the combination of work overload and low autonomy concerning the environment are related to poor wellbeing, performance, and health of workers. Empirical evidence lends support to this model. Vanroelen, Levecque and Louckx (2009) found that high work demands are associated with a high prevalence of fatigue and emotional problems. In turn, Mausner-Dorsch and Eaton (2000) found that overload and conflicts at work are related to major depressive episodes, depressive syndrome, and dysphoria.

Another study worthy of mention is the survey of Chen et al. (2009). These authors found that workers exposed to high levels of stress at work were more likely to have depressive symptoms. The findings of this study corroborated research in different countries (Eaton, Anthony, Mandel, \& Garrison, 1990; Mausner-Dorsch \& Eaton, 2000; Plaisier et al., 2007) which also found relationships between work stressors and psychopathologies.

Although the mechanism which regulate the relationship between becoming mentally ill and working conditions are not well known, it is possible that people who work in unsuitable conditions (with low autonomy and without adequate social support) and who undergo constantly stressful events also experience high levels of negative affects. The frequency with which one experiences negative affects can be directly associated with the level of emotional neuroticism/disadjustment (Steel, Schmidt, \& Shultz, 2008). In other words, it is possible that workers exposed to more adverse working conditions experience more negative affects and have higher levels of mental illness than workers exposed to less adverse conditions. In this respect, the chronification of feelings as frustration, anguish and lack of adaptation to the work environment provided by the work organization may be responsible for leading to psychopathologies. The study of Kendler, Kuhn and Prescott (2004) provides some support for this hypothesis, as the authors found that the interrelations between psychosocial adversity (negative stressful events) and emotional disadjustment compose the etiology of major depression.

\section{Description of the Working Conditions in Poultry Slaughterhouses}

Albuquerque (2007), in a previous study, asked production line employees in which sectors it was worst to work. The cutting room was awarded first place. In this sector the employees have the function of killing the chickens. In second place were the sectors for receiving chickens (the sector where the birds are delivered to the slaughterhouse); evisceration (the sector in which the entrails of the chickens are removed), packaging (the sector in which the chickens are packaged to be sent to the consumer) and freezing (the sector in which the birds are cooled). In third place were the bleeding sectors (the sector in which the blood is drained from the birds); plucking (the sector in which the feathers are removed from the chickens) and loading (the sector responsible for transporting the chickens inside the slaughterhouse). The activities and the work environment of the sectors described by Albuquerque (2007) which were investigated in the present study are described in Table 1.

As can be seen from the descriptions in Table 1, the production line workers of the cold storage plants are exposed to physically adverse working conditions. For example, the workers perform their activities in a totally white, cold (approximately $7^{\circ} \mathrm{C}$ ) environment, with high humidity in the air and pervaded by a disagreeable odor of excrement. The workers execute repetitive movements in work places of inadequate dimensions and, in most cases, standing all the time that they are working $(\mathrm{H}$. B. Neto, personal communication, September 14, 2009). Furthermore, the work is regulated by the speed of the moving belt (the conveyor which transports the chicken between the sectors) which forces the employees to work at a speed which is too high (Albuquerque, 2007).

It should also be noted that the interpersonal and power relations which are established between the employees can jeopardize the collective wellbeing. The workers are instructed not to talk during the activities; they cannot stop working when they want without requesting authorization and work under the eye of a supervisor of the production line who controls the productivity with constant oral warnings and frequent humiliation (H. B. Neto, personal communication, September 14, 2009). The function of the supervisor is to ensure that the workers achieve their attributions with perfection and in accordance with the speed imposed by the conveyor - which frequently is very high - (H. B. Neto, personal communication, September 14, 2009). 
Table 1

Adversities and Risk Factors Related to the Activities Developed in the Different Production Sectors

\begin{tabular}{|c|c|c|}
\hline Sector & Activities developed & Adversities of the work environment \\
\hline Cutting & $\begin{array}{l}\text { Cuts of several types, boning, } \\
\text { preparation for evisceration. }\end{array}$ & $\begin{array}{l}\text { Intense cold }\left(7^{\circ} \mathrm{C}\right) \text {, humidity, dirt of entrails and excre- } \\
\text { ment, splashes of blood on the face and body, repetitive } \\
\text { work under intense pressure from the supervisors, im- } \\
\text { possibility of interaction due to the intense noise, com- } \\
\text { plaints of harassment and humiliation. }\end{array}$ \\
\hline Evisceration & $\begin{array}{l}\text { Separation of giblets, clea- } \\
\text { ning of gizzard removed and } \\
\text { classification of the feet, re- } \\
\text { moval of imperfections of the } \\
\text { chicken. }\end{array}$ & $\begin{array}{l}\text { Humidity, dirt, intense odor, repetitive work, pressure } \\
\text { from production, impossibility of interaction due to the } \\
\text { intense noise, pressure from the supervisors. }\end{array}$ \\
\hline Reception & $\begin{array}{l}\text { Loading, transporting crates } \\
\text { with chickens in them. }\end{array}$ & $\begin{array}{l}\text { Great physical effort to unload the crates of chicken, fe- } \\
\text { tid odor, biological risks, clothes in a precarious state } \\
\text { due to the dirt and wear, ventilators aimed at the brea- } \\
\text { thing area of the worker, causing chemical and biologi- } \\
\text { cal risks, serious risks of falling and being crushed. }\end{array}$ \\
\hline Packaging & Packaging chickens. & Repetitive work, restricted physical space. \\
\hline Freezing & $\begin{array}{l}\text { Transporting the packaged } \\
\text { chickens for storage. }\end{array}$ & Cold and humidity. \\
\hline
\end{tabular}

The cutting room, according to what the employees report, is the sector which most exposes the workers to stressful agents (Albuquerque, 2007). These workers, besides being subject to all the physical and emotional agents described above, have the function of cutting chickens during approximately eight hours per day. Furthermore, the workers receive squirts of blood, repeatedly, owing to cutting the birds neck manually (a requirement of some importers). The employees of this sector work in the presence of entrails, and excrement accumulated on the floor, which remains damp and dirty during all the day's work.

The sectors of reception, evisceration, packaging, freezing, bleeding, plucking and loading have particularities and different levels of exposure to stressful agents (Albuquerque, 2007). However, the employees of these sectors are less exposed to risk factors than the cutting sector because they are not directly involved with slaughtering the animals.

Based on the descriptions above, it is plausible to assume that these workers, exposed to different stressors daily, might have high scores of indicators of psychopathologies. As it is possible that workers of slaughterhouses fall ill owing to the organization of the work to which they are subjected, it is justifiable to intervene by evaluating indicators of development of psychopathologies in these employees.

Therefore, the main objective of the present study was to compare the levels of anxiety, depression, vulnerability, psychosocial disadjustment of administrative and production line workers of slaughterhouses. Administrative workers are not exposed to the stressful agents to which workers in the production line are. More specifically, this study compared the levels of these variables in employees: (a) of the cutting sector (more exposed to stressors), (b) of the other sectors also exposed to stressors, and (c) of the administrative sectors (not exposed to the stressors of the production line). Another objective was to compare the levels of these variables between: (a) a group formed by all the employees of the production line of the slaughterhouses, (b) a group of workers of a university who were undergoing stressful work conditions, and (c) a group of university students (as a comparison group).

\section{Method}

\section{Participants}

The participants were 951 workers of four poultry slaughterhouses in southern Brazil. Approximately $63.5 \%$ 
Hutz, C. S., Zanon, C. \& Brum Neto, H. (2013). Adverse Working Conditions and Mental Illness in Poultry Slaughterhouses in Southern Brazil.

of the workers were female and $36.5 \%$ were male. The average age was 31.6 years $(S D=8.9)$. About $43 \%$ of the workers were from cutting sector, $21 \%$ from packaging, $12 \%$ from evisceration, $4 \%$ from freezing, $2 \%$ from reception, $11 \%$ from administration, and $7 \%$ from other sectors of the production line. The participants were selected from the payroll of the companies through a random allotment of names.

The data of university students and workers of a university with campi in several Brazilian states that were used to compare with the scores of the slaughterhouse workers were removed from the databases of other research by Vazquez, Zanon, and Hutz (2010) and Zanon and Hutz (2010). There were 361 university students (48.5\% female and $51.5 \%$ male), with an average age of 19.9 years (SD =3.6). The university workers were 156 technical and administrative employees the institution (46.6\% male and $53.4 \%$ female) with an average age of 28.4 years $(S D=8.3)$.

\section{Instrument}

The Neuroticism Factorial Scale (EFN; Hutz \& Nunes, 2001) has four subfactors: vulnerability, psychosocial disadjustment, anxiety and depression. The EFN is a selfreport instrument which quickly and objectively evaluates characteristics of emotional instability and adjustment (Hutz \& Nunes, 2001). This test was developed within the model of the Big Five Personality Factors, which conceives human personality from five big dimensions: Neuroticism, Extraversion, Agreeableness, Conscientiousness, and Openness. The Neuroticism factor is composed of subdimensions which group symptoms and predispositions to impulsiveness, hostility, depression, anxiety, vulnerability, etc. (McCrae \& John, 1992). In the EFN, specifically, four facets were identified: Vulnerability, Psychosocial Disadjustment, Anxiety and Depression (Hutz \& Nunes, 2001).

This instrument has 82 items that are answered in a 7-point Likert scale anchored at the ends (" 1 " means that the person completely disagrees that the sentence describes one of his/her characteristics and " 7 " means that the participant fully agrees that the sentence describes him/ her suitably.

Vulnerability groups items that describe fear of criticism, insecurity, and difficulty to make decisions. Psychosocial Disadjustment is composed of items which describe disregard for social rules, risky sexual behavior and an exaggerated consumption of alcohol. Anxiety contains items which deal with disorders related to anxiety, irritability and hostility. The last facet, Depression, groups items which describe notions of suicide, pessimism and lack of objectives in life. The EFN was validated for use in Brazil and has appropriate internal consistency indexes (Cronbach's alpha) in its facets, which vary from .82 thru .93 (Hutz \& Nunes, 2001).

\section{Procedures}

The participants answered the questionnaires collectively. At first, a rapport was established by presenting the test instructions. Then, the voluntary and non-mandatory nature of participation was explained, as well as ensuring the non-disclosure and anonymity of the information obtained. The data were collected in a single session for each group of approximately 50 workers. The total time used for applying the test was about 35 minutes per group.

\section{Results}

First, a comparison was made of averages of vulnerability, psychosocial disadjustment, anxiety and depression between work sectors of the slaughterhouses. The averages of these variables of workers of the slaughterhouses (excluding those who had administrative functions) were compared with the group of workers of a university who were working in stressful conditions and with a sample of university students. Then, the averages of employees of the administrative sector were compared with the averages of university students. All the comparisons of averages were done through univariate analyses of variance (ANOVA). The averages and standard deviations of the sectors and groups related to the variables investigated are presented in Table 2. Finally, the frequency with which the workers of the slaughterhouses (of the production and administrative lines) answered some specific items of the EFN was analyzed.

To evaluate possible differences of vulnerability, psychosocial disadjustment, anxiety and depression, the scores of workers of the cutting sector of the slaughterhouses (sector of high exposure to risk factors, see Table 1) were compared with workers of the sectors of evisceration, reception, packaging and freezing (sectors of average exposure to risk factors) and with the administrative staff (workers little exposed to risk factors). The workers of the cutting sector had higher averages in the four variables than the workers in the other sectors. The ANOVAs revealed significant differences between the groups related to vulnerability $[F(2,754)=45.4, p<.001]$, psychosocial disadjustment $[F(2,779)=11.8, p<.001]$, anxiety $[F(2,739)=57.2, p$ $<.001]$ and depression $[F(2,739)=46.0, p<.001]$. Post hoc tests (Scheffe) were used to check which sectors had significant differences between them.

Significant differences in vulnerability were found between the workers of the cutting and the administrative sector $(p<.001, d=1.0)$. The " $d$ " is an estimate of the effect size as a percentage of a standard deviation (Cohen, 1988). A significant difference was found also between the workers of the evisceration, reception, packaging and freezing sectors and the administrative staff $(p<.001, d$ $=.8$ ).

Concerning psychosocial disadjustment, significant differences were found between workers of the cutting sector and the administrative staff $(p<.001, d=.5)$. A significant difference was also found between workers of the evisceration, reception, packaging and freezing sectors and the administrative staff $(p<.001, d=.4)$. 
Table 2

Means and Standard-Deviations of the Research Variables by Sectors and Groups

\begin{tabular}{|c|c|c|c|c|c|c|}
\hline \multirow{3}{*}{ Variables } & \multicolumn{6}{|c|}{ Sectors } \\
\hline & \multicolumn{2}{|c|}{ Cutting } & \multicolumn{2}{|c|}{$\begin{array}{l}\text { Evisceration, reception, } \\
\text { packaging, freezing }\end{array}$} & \multicolumn{2}{|c|}{ Administration } \\
\hline & $M$ & $S D$ & $M$ & $S D$ & $M$ & $S D$ \\
\hline Vulnerability & 77.6 & 25.4 & 73.0 & 26.4 & 50.9 & 17.1 \\
\hline Psychosocial disadjustment & 26.6 & 15.0 & 25.1 & 12.5 & 19.4 & 9.6 \\
\hline Anxiety & 86.8 & 31.1 & 77.4 & 30.4 & 50.9 & 21.4 \\
\hline \multirow[t]{2}{*}{ Depression } & 56.1 & 22.4 & 50.1 & 19.7 & 33.6 & 15.6 \\
\hline & \multicolumn{6}{|c|}{ Groups } \\
\hline \multirow{2}{*}{ Variables } & \multicolumn{2}{|c|}{ Slaughterhouse workers } & \multicolumn{2}{|c|}{ University workers } & \multicolumn{2}{|c|}{ Students } \\
\hline & $M$ & $S D$ & $M$ & $S D$ & $M$ & $S D$ \\
\hline Vulnerability & 75.8 & 25.7 & 66.9 & 25.1 & 54.7 & 20.1 \\
\hline Psychosocial disadjustment & 26.9 & 14.4 & 26.2 & 15.0 & 19.4 & 8.7 \\
\hline Anxiety & 82.4 & 30.7 & 68.4 & 28.3 & 55.9 & 22.0 \\
\hline Depression & 53.6 & 20.6 & 48.0 & 20.6 & 34.2 & 14.3 \\
\hline
\end{tabular}

Significant anxiety differences were found between the workers of the cutting sector and the administrative staff $(p<.001, d=1.1)$ and with the other workers ( $p$ $<.001, d=.3)$. An anxiety difference was also found between workers of the evisceration, reception, packaging and freezing sectors with the administrative staff ( $p$ $<.001, d=.8$ ).

Finally, depression was also significantly higher between the workers of the cutting sector as compared to the administrative staff $(p<.001, d=1.0)$ and with the other workers ( $p<.001, d=.3$ ). A difference of depression was also found between workers of the evisceration, reception, packaging and freezing sectors and the administrative staff $(p<.001, d=.7)$. Figure 1 and Figure 2 show the depression and anxiety mean differences in the three different sectors.

To assess possible differences of vulnerability, psychosocial disadjustment, anxiety and depression, the scores of the workers of the slaughterhouses (all the sectors, except for the administrative ones) were compared with the scores of university workers who were undergoing stressful conditions and with university students (group used for comparison). The workers of the slaughterhouses presented higher averages than the other groups in vulnerability, anxiety and depression. The ANOVAs revealed significant differences between the groups regarding vulnerability $[F$ $(2,1211)=73.6, p<.001]$, psychosocial disadjustment $[F$ $(2,1211)=30.4, p<.001]$, anxiety $[F(2,1211)=86.6, p<$ $.001]$ and depression $[F(2,1211)=97.95, p<.001]$. Post $h o c$ tests (Scheffe) were used to check which groups were significantly different from each other.

Anxiety was significantly higher in workers of the slaughterhouses than in students $(p<.001, d=.8)$ or in university workers $(p<.001, d=.4)$. However, University workers were, as expected, higher in anxiety than the students $(p<.001, d=.4)$. Workers of the slaughterhouses were higher in depression than the students $(p<.001, d$ $=.9)$ and the university workers $(p<.001, d=.3)$ and between the workers of the university and the students $(p$ $<.001, d=.7)$. 
Hutz, C. S., Zanon, C. \& Brum Neto, H. (2013). Adverse Working Conditions and Mental Illness in Poultry Slaughterhouses in Southern Brazil.

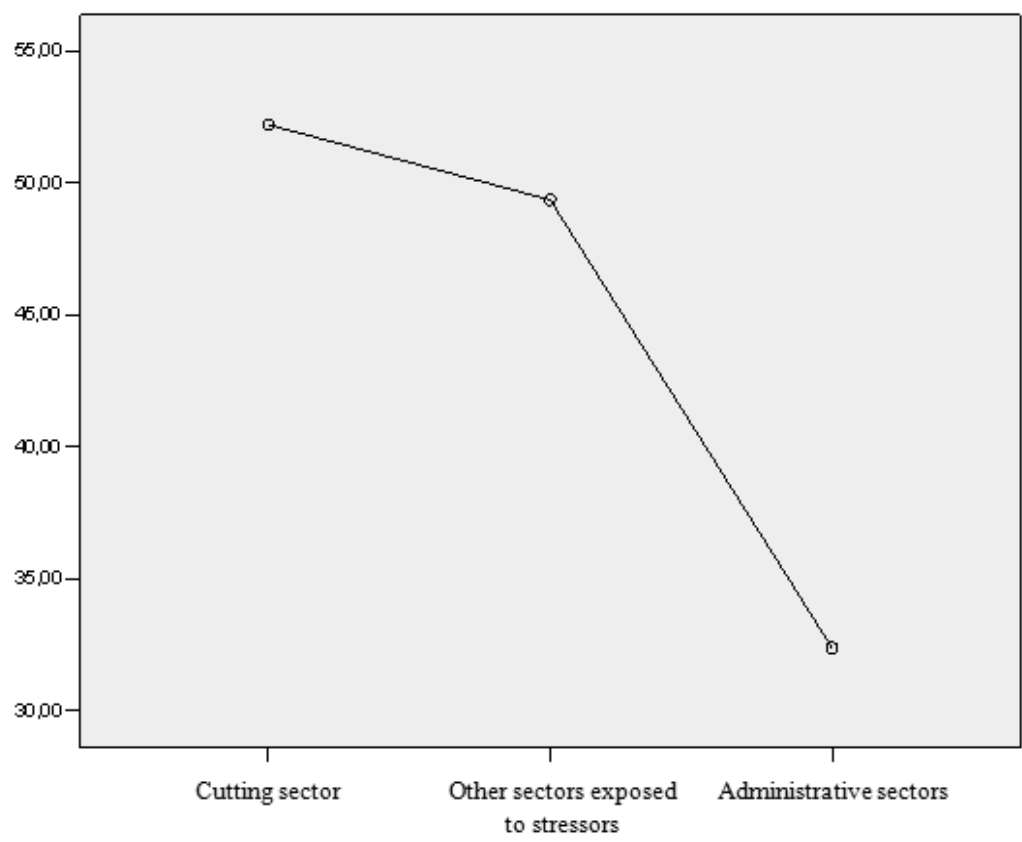

Figure 1. Depression mean differences among the cutting sector, other sectors exposed to stressors and administrative sectors.

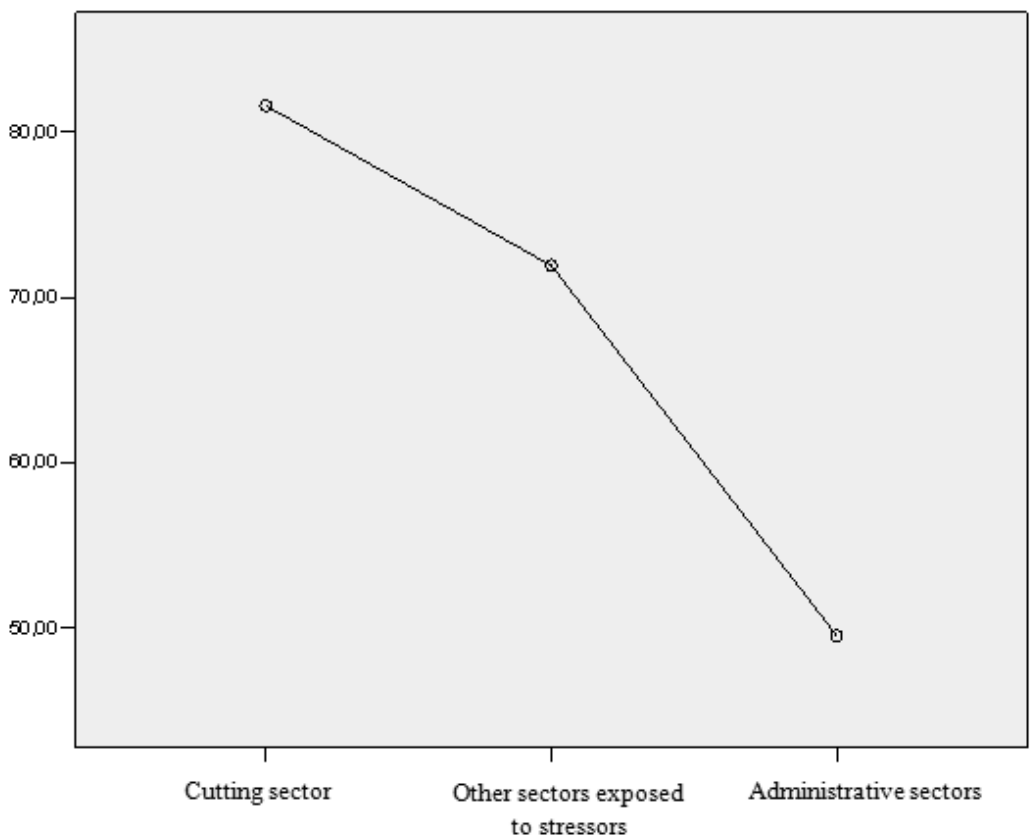

Figure 2. Anxiety mean differences among the cutting sector, other sectors exposed to stressors and administrative sectors.

Differences in vulnerability were found between the workers of the slaughterhouses and the students $(p<.001$, $d=.8)$ and the workers of the university $(p<.001, d=$ .3). A difference in vulnerability was also found between university workers and students $(p<.001, d=.5)$. There were also differences in psychosocial disadjustment be- tween workers of the slaughterhouses and the students ( $p$ $<.001, d=.5$ ) and between workers of the university and the students $(p<.001, d=.5)$.

Then, two groups not exposed to the stressors that are present in the production lines of the slaughterhouses were compared: undergraduate students and administrative 
workers. Both groups had similar averages of vulnerability, psychosocial disadjustment, anxiety and depression. The ANOVAs did not show significant differences of vulnerability $[F(1,361)=1.82, p>.05, d=.2]$, psychosocial disadjustment $[F(1,361)<1]$, anxiety $[F(1,361)=3.39$, $p>0.05, d=.2]$, and depression $[F(1,361)<1]$ between the groups. Figure 3 and Figure 4 show the depression and anxiety mean differences in the three different groups.

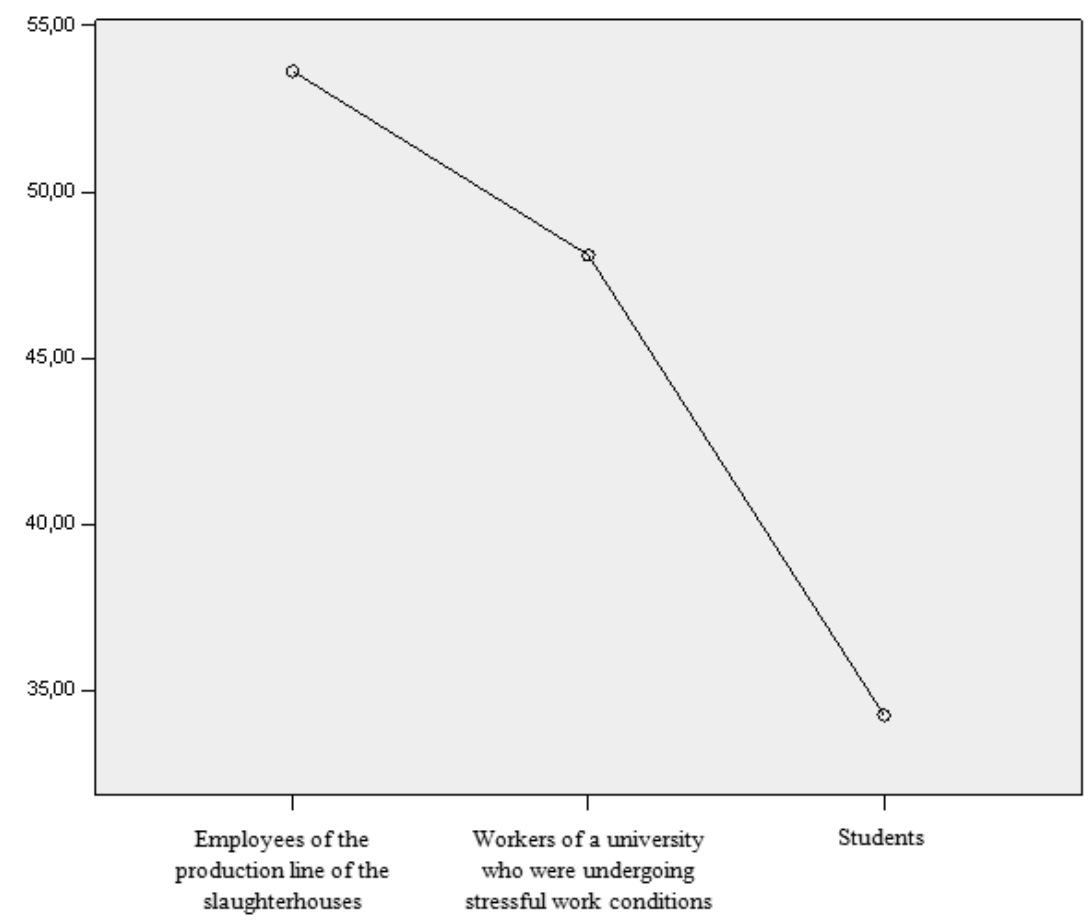

Figure 3. Depression mean differences among the employees of the production line of the slaughterhouses, workers of a university who were undergoing stressful work conditions and undergraduate students.

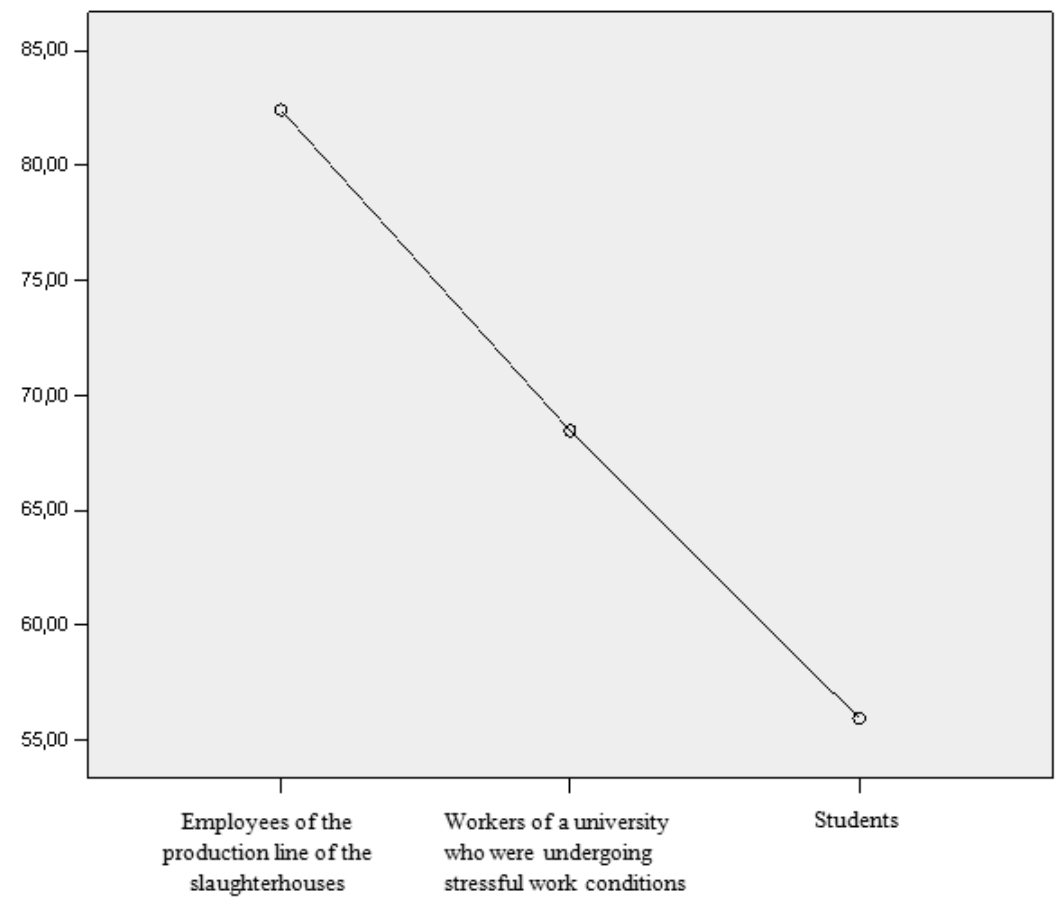

Figure 4. Anxiety mean differences among the employees of the production line of the slaughterhouses, workers of a university who were undergoing stressful work conditions and undergraduate students. 
Hutz, C. S., Zanon, C. \& Brum Neto, H. (2013). Adverse Working Conditions and Mental Illness in Poultry Slaughterhouses in Southern Brazil.

Finally, it was found that 97 workers of the production line of the slaughterhouses (10.2\%) marked "7" for item 35 of the NFS which says: "I have already tried to commit suicide"; 66 workers (8\%) marked "7" for item 39: "I have already told other people that I would commit suicide"; 106 workers (11\%) marked "7" for item 69: "Sometimes I have fits of rage in which I wound myself". The answer percentages of administrative workers to these items are as follows: 2 subjects (1.9\%) marked "7" for item 35; 1 subject ( $1 \%$ ) marked “7” for item 39; 2 subjects (1.9\%) marked "7" for item 69 .

\section{Discussion}

The scientific value of this study lies in the results and conclusions which it indicates, i.e., the work environment can affect the mental health of employees. It showed that workers of the slaughterhouses (production sector) had high levels of depression, anxiety, disadjustment, and vulnerability.

The cutting sector had the highest indexes of psychopathologies, followed by the reception, evisceration, packaging and freezing sectors. In turn, the administrative workers (not exposed to stressful agents) had the lowest averages. This finding supports the conclusion of Chen et al. (2009) who noted that the level of exposure to stressful factors is associated with the level of depression. It can also be seen in this study that the averages of anxiety, psychosocial disadjustment and vulnerability were also higher in the sectors more exposed to stressors. From this data, it is plausible to think that the people of the cutting sector are more vulnerable and have higher indexes of psychopathological symptoms due to the greater exposure to aggressive agents created by the current configuration of the work organization.

The workers of the slaughterhouses had higher averages of depression, anxiety and vulnerability than other employees who worked in stressful conditions. It is plausible to assume that the working conditions in slaughterhouses are extremely adverse and expose workers to high risks of psychopathologies. This hypothesis gains support to the extent to which it is perceived that the university students (not exposed to work stressors) have low scores of psychopathologies.

Finally, comparing the two other groups (not exposed to work stressors) no statistically significant differences of depression, anxiety, vulnerability and psychosocial disadjustment were found

The answers to specific items reveal that many employees have already mutilated themselves in fits of rage, have already commented to someone that they might commit suicide, and have already tried to kill themselves. These data indicate the need for intervening to reduce the psychic suffering of these workers urgently.

As a conclusion, it is suggested that the work environment is related to the mental health of the workers. Despite the fact that this description does not allow to infer direct causality between these variables, this likelihood is reinforced by the differences found between sectors, which indicates that the high indexes of anxiety and depression cannot be attributed solely to characteristics of the community or individual idiosyncrasies.

\section{References}

Albuquerque, P. P. (2007). Doenças do trabalhador: A irresponsabilidade social do capital [Illnesses of the worker: The social irresponsibility of the capital]. São Leopoldo, RS: Nova Harmonia.

Borsoi, I. C. F. (2007). Da relação entre trabalho e saúde à relação entre trabalho e saúde mental [From the relationship between work and health to the relationship between work and mental health]. Psicologia e Sociedade, 19, 103-111.

Chen, W. Q., Siu, O. L., Lu, J. F., Cooper, C. L., \& Phillips, D. R. (2009). Work stress and depression: The direct and moderating effects of informal social support and coping. Stress and Health, 25, 431-443.

Cohen, J. (1988). Statistical power analysis for the behavioral sciences $\left(2^{\text {nd }}\right.$ ed.). Hillsdale, NJ: Erlbaum.

Eaton, W. W., Anthony, J. C., Mandel, W., \& Garrison, R. (1990). Occupations and the prevalence of major depressive disorder. Journal of Occupational Medicine, 32(11), 1079-1087.

Hutz, C. S., \& Nunes, C. H. S. S. (2001). Escala Fatorial de Ajustamento Emocional/Neuroticismo [Factorial Scale of Neuroticism]. São Paulo, SP: Casa do Psicólogo.

International Labor Office. (2010). ILO Governing Body approves new list of occupational diseases. Retrieved from http://www. ilo.org/safework/whatsnew/lang--en/WCMS_124671/index. htm

Karasek, R. A. (1979). Job demands, job decision latitude, and mental strain: Implications for job redesign. Administrative Science Quarterly, 24, 285-307.

Kendler, K. S., Kuhn, J., \& Prescott, C. A. (2004). The interrelationship of neuroticism, sex, and stressful life events in the prediction of episodes of major depression. American Journal of Psychiatry, 161, 631-636.

Mausner-Dorsch, H., \& Eaton, W. W. (2000). Psychosocial work environment and depression: Epidemiologic assessment of the demand-control model. American Journal of Public Health, 90(11), 1765-1770.

McCrae, R. R., \& John, O. P. (1992). An introduction to the five-factor model and its applications. Journal of Personality, 60(2), 175-215

Ministry of Social Security. (2010). Acompanhamento mensal dos benefícios auxílios-doença previdenciários concedidos segundo os códigos da CID-10 [Monthly follow up of health benefits and payments for deseases according IDC-10 codes]. Retrieved from http://www.inss.gov.br/arquivos/office/4_100111-115547-873.pdf

Plaisier, I., Bruijn, J. G. M., Graaf, R., Have, M., Beekman, A. T. F., \& Penninx, B. W. J. H. (2007). The contribution of working conditions and social support to the onset of depressive and anxiety disorders among male and female employees. Social Science \& Medicine, 64(2), 401-410.

Steel, P., Schmidt, J., \& Schultz, J. (2008). Refining the relationship between personality and subjective well-being. Psychological Bulletin, 134(1), 138-161. 
União Brasileira de Avicultura. (2011). Relatório anual Ubabef 2010/2011. Retrieved from http://www.abef.com.br/ubabef/ exibenoticiaubabef.php?notcodigo $=2761$

Vanroelen, C., Levecque, K., \& Louckx, F. (2009). Psychosocial working conditions and self-reported health in a representative sample of wage-earners: A test of the different hypotheses of the demand-control-support-model. International Archives of Occupational and Environmental Health, 82, 329-342.

Vazquez, A. C., Zanon, C., \& Hutz, C. S. (2010). Estabilidade temporal da Escala Fatorial de Neuroticismo [Temporal stability of the Factorial Scale of Neuroticism]. Avaliação Psicológica, 9, 333-335.

Zanon, C., \& Hutz, C. S. (2010). Relações entre bem-estar subjetivo, neuroticismo, ruminação, reflexão e sexo. Gerais: Revista Interinstitucional de Psicologia, 2, 118-127. 